\title{
Nickel removal from wastewater by electrocoagulation with aluminum electrodes
}

\author{
K. Dermentzis ${ }^{*}, 1$, E. Valsamidou ${ }^{2}$, A. Lazaridou ${ }^{2}$ and N. C. Kokkinos ${ }^{2}$ \\ ${ }^{1}$ Dep. of Science, Laboratory of Chemical Technology - Electrochemistry, Kavala Institute of Technology, 65404 St. Loukas, Kavala, \\ Greece, \\ ${ }^{2}$ Dep. of Petroleum and Natural Gas Technology, Laboratory of Environment Protection, Kavala Institute of Technology, 65404 St. \\ Loukas, Kavala, Greece
}

Received 29 July 2010; Revised 25 January 2011; Accepted 9 November 2011

\begin{abstract}
In this study, the performance of electrocoagulation with aluminium electrodes for removing nickel from synthetic aqueous solutions and actual electroplating wastewater was investigated. Parameters affecting the electrocoagulation process, such as initial $\mathrm{pH}$, current density, initial metal ion concentration and contact time were investigated. The removal efficiency is very high in the $\mathrm{pH}$ range 4-10. Increased current density accelerated the electrocoagulation process, however, on cost of increased energy consumption. Initial $\mathrm{Ni}^{2+}$ concentrations of $100-300 \mathrm{mg} / \mathrm{lit}$ were quantitatively reduced under the admissible limits in only 10-20 minutes of electrolysis time respectively at the current density of $30 \mathrm{~mA} / \mathrm{cm}^{2}$. The process has proved to be efficient in removing $\mathrm{Ni}^{2+}$ ions also from industrial electroplating effluents, where an initial $\mathrm{Ni}^{2+}$ concentration of $215 \mathrm{mg} /$ lit fell under the legal limits in 20 minutes.
\end{abstract}

Keywords: electrocoagulation, electroflotation, sacrificial aluminium anode, electroplating effluent.

\section{Introduction}

Industrial effluents from nickel electroplating industries contain high amounts of nickel ions, which are of considerable concern because they are non-biodegradable and highly toxic. Only $30-40 \%$ of the metal used in plating processes are effectively utilized i.e. plated on the articles. The rest contaminates the rinse waters during the plating process when the plated objects are rinsed upon removal from the plating bath. Nickel is a toxic heavy metal and nickel compounds, for instance nickel sulphide, are suspected to cause cancer [1]. Waste streams from nickel electroplating industries may contain up to $500 \mathrm{ppm} \mathrm{Ni}^{2+}$ ions, which according to environmental regulations worldwide must be controlled to an acceptable level $(<2$ ppm) before being discharged to the environment.

Several treatment processes have been suggested for the removal of nickel ions from aqueous waste streams: adsorption [2,3], biosorption [4,5], ion exchange [6], chemical precipitation $[7,8]$ and electrochemical methods: electrowinning [9.10], electrodialysis [11], electrodeionization [12,13], membrane-less electrostatic shielding based electrodialysis/electrodeionization [14-16] and electrocoagulation.

Hydroxide precipitation is the most common conventional treatment applied to the metal plating wastewaters to remove heavy metals. The method is based on low solubility of metal hydroxides at alkaline $\mathrm{pH}$ values. As the metals are converted to metal hydroxide solid phase they are separated from wastewater by physical means such

* E-mail address: demerz@otenet.gr ISSN: 1791-2377 (C) 2011 Kavala Institute of Technology. All rights reserved. as sedimentation, flotation and filtration. Hydroxide precipitation performance on free metal removal is perfect at the optimum $\mathrm{pH}$ where metal solubility is the lowest. The optimum $\mathrm{pH}$ value for nickel is 10.2. The obtained nickel solubility at this optimum $\mathrm{pH}$ is about $0.001 \mathrm{mg} / \mathrm{L}$. On the other hand, metal plating baths are not prepared using only metal salts and the recipe of the metal plating bath generally includes complexing agent, carrier, brightener, one or more than one metal salts and chloride or other salts. The complexing agent is used in the metal plating baths to prevent the metals from being precipitated. In this case, a wastewater containing complexing agents cannot be treated to remove metals by hydroxide precipitation within the limits of usual operation and it requires its modification called as high $\mathrm{pH}$ hydroxide precipitation [Tünay and Kabdaşlı (7), Tünay et al.(17)] or another treatment method application such as sulphide precipitation, electrocoagulation etc. Sulphide precipitation based on low solubility of metal sulfides is also applied to metal bearing wastewaters to remove heavy metals. This method is very efficient in free and particularly complexed metals. The amount of sludge produced by sulphide precipitation is higher than that produced by hydroxide precipitation. Handling and disposal of the sludge produced by sulphide precipitation is difficult due to its hazardous nature.

The solid phases initially formed may be very finally divided during hydroxide precipitation and hard to separate by gravity. Sodium hydroxide using $\mathrm{pH}$ adjustment generally causes to form smaller particles but upon coagulation they yield a very clear supernatant. The best solution to solid formation and separation problem is the use of inorganic and organic coagulants. For this purpose, $\mathrm{FeCl}_{3}$, alum, and various polyelectrolytes are commonly used as 
coagulant aid agents in the hydroxide precipitation application.

The amounts of the precipitated sludge containing the concentrated nickel hydroxides or sulfides are an extremely hazardous waste and must be disposed of using special facilities at great expense to industry. From the viewpoint of environmental protection and resource saving, effective recycling and reusing of the nickel containing wastewater is strongly expected. Closed-recycle system or so-called effluent-free technology should be developed.

Electrocoagulation uses no chemicals as coagulating agents. These are generated during the electrolysis process by electrodissolution of a sacrificial anode made of aluminium or iron. Electrocoagulation has been successfully performed for treatment and remediation of textile wastewaters [18,19], oil wastes [20,21], diary effluents [22], diesel and biodiesel wastewaters $[23,24]$, laundry wastewaters [25], slaughter house effluents [26], arsenic or fluoride containing waters $[27,28]$ and heavy metal bearing effluents [29-34].

This paper reports the efficiency of electrocoagulation in removing metallic pollutants, such as nickel ions from synthetic aqueous solutions and actual electroplating wastewater.

\section{Materials and Methods}

\subsection{Chemicals}

$\mathrm{NiSO}_{4} \cdot 7 \mathrm{H}_{2} \mathrm{O}, \mathrm{KCl}$ and $\mathrm{NaOH}$ were of analytical grade (Merck). $\mathrm{pH}$ was adjusted by $0.1 \mathrm{M}$ solutions of $\mathrm{HCl}$ and $\mathrm{NaOH}$ as required. The actual wastewater was obtained from an electroplating unit located near Thessaloniki, northern Greece. Its main characteristics are listed in Table 1.

Table 1. Main characteristics of the actual wastewater sample

\begin{tabular}{ll|c}
\multicolumn{2}{l|}{ sample } & \\
\hline $\mathbf{p H}$ & & 6.5 \\
$\mathbf{C o n d u c t i v i t y}$ & $(\mathbf{m S} / \mathbf{c m})$ & 1.4 \\
$\mathbf{C O D}$ & $\mathbf{( m g / L )}$ & 324 \\
$\mathbf{N i}^{2+}$ & $\mathbf{( m g / L )}$ & 215 \\
$\mathbf{C l}^{-}$ & $\mathbf{( m g / L )}$ & 40 \\
$\mathbf{S O}_{4}{ }^{2-}$ & $\mathbf{( m g / L )}$ & 275 \\
\hline
\end{tabular}

\subsection{Apparatus}

A laboratory model DC power supply apparatus (PHYWE, STELL TRAFO, PHYWE Systeme GmbH \& Co. KG. Germany) was used to maintain constant DC current. Voltage and current were measured by a multimeter (PHYWE). Conductivity was measured by means of a conductometer (inoLab Cond. Level 1, WTW). The $\mathrm{pH}$ and the temperature were measured using a Hanna (HI8314) pHmeter connected to a combined electrode comprising a temperature sensor (HI1217D).

Electrolyses were conducted at room temperature in a cylindrical glass cell of $500 \mathrm{ml}$ in which aliquot solutions of $250 \mathrm{ml}$ were placed and slowly stirred with a magnetic bar at $500 \mathrm{rpm}$. Four commercially obtained aluminium plates of size $10 \mathrm{~cm} \times 5 \mathrm{~cm} \times 0.5 \mathrm{~cm}$ immersed to a $5 \mathrm{~cm}$ depth with an effective area of $20 \mathrm{~cm}^{2}$ each, were used as electrodes in the experiments. The electrodes were connected in a monopolar mode with a total anode surface of $60 \mathrm{~cm}^{2}$. The interelectrode distance was $1.5 \mathrm{~cm}$. To remove the oxide and passivation layer from aluminium surface the electrodes were grinded with sandpaper and energized by dipping them in $\mathrm{HCl} 5 \mathrm{~N} \mathrm{KCl}$ for 1 minute. $0.5 \mathrm{~g} \mathrm{KCl}$ was added to every treated solution. The added $\mathrm{KCl}$ serves for prevention of passivation on the aluminium electrode surface and decrease of the excessive ohmic drop in the solution.

Samples were extracted every 5 minutes, filtered using Whatman filter paper (Grade 40). The residual nickel and aluminium concentrations were determined by Atomic Absorption Spectroscopy AAS (Perkin Elmer 5100), whereas the concentrations of $\mathrm{Cl}^{-}$and $\mathrm{SO}_{4}{ }^{2-}$ ions were measured by UV spectrophotometry (Hitachi 2000).

The chemical oxygen demand (COD) was analyzed using a COD reactor (Thermoreaktor TR 420, MERCK) and a direct reading spectrophotometer (Spectroquant Pharo100, MERCK).

At the end of each experiment the produced sludge was measured.

\subsection{Brief description of electrocoagulation}

Electrocoagulation is a process consisting of creating metallic hydroxide flocks inside the wastewater by electrodissolution of soluble anodes made of aluminium or iron. The main reactions occurring during electrocoagulation produce aluminium ions at the sacrificial anode and hydroxide ions as well hydrogen gas at the cathode:

$\mathrm{Al} \rightarrow \mathrm{Al}^{3}+3 \mathrm{e}^{-}$

(anode)

$2 \mathrm{H}_{2} \mathrm{O}+2 \mathrm{e}^{-} \rightarrow 2 \mathrm{OH}^{-}+\mathrm{H}_{2}$

(cathode)

The generated $\mathrm{Al}^{3+}$ and $\mathrm{OH}^{-}$ions react to form various monomeric and polymeric species such as $\mathrm{Al}(\mathrm{OH})^{2+}$, $\mathrm{Al}(\mathrm{OH})_{2}{ }^{+}, \mathrm{Al}_{2}(\mathrm{OH})_{2}{ }^{4+}, \mathrm{Al}(\mathrm{OH})^{4-}, \mathrm{Al}_{6}(\mathrm{OH})_{15}{ }^{3+}, \mathrm{Al}_{7}(\mathrm{OH})_{17}{ }^{4+}$, $\mathrm{Al}_{8}(\mathrm{OH})_{20}{ }^{7+}, \quad \mathrm{Al}_{13} \mathrm{O}_{4}(\mathrm{OH})_{24}{ }^{7+}, \quad \mathrm{Al}_{13}(\mathrm{OH})_{34}{ }^{5+}$ which finally result in situ formation of gelatinous $\mathrm{Al}(\mathrm{OH})_{3}$ effecting the coagulation and co-precipitation or $\mathrm{H}_{2}$ flotation of particulates from the solution by adsorption [Kobya et al, (18)]. The aluminium hydroxide flocks act as absorbents for heavy metal ions. Furthermore, heavy metal ions combine with the electro-generated $\mathrm{OH}^{-}$ions at the cathode and precipitate in form of their insoluble hydroxides. Both phenomena act synergistically leading to a rapid removal of heavy metal pollutants from water.

\section{Results and Discussion}

\subsection{Effects of operating parameters}

The electrocoagulation process is affected by several operating parameters, such as initial $\mathrm{pH}$, pollutants concentrations, current density and contact time. In the present study all these have been explored in order to evaluate a treatment technology for nickel removal from synthetic solutions and actual electroplating wastewaters.

\subsubsection{Initial pH}

According to literature, $\mathrm{pH}$ has a considerable effect on the efficiency of the electrocoagulation process. In addition, $\mathrm{pH}$ changes during the process dependent on the anode material and the initial $\mathrm{pH}$ value of the treated solution. Vik et al. [35] reported that the observed increase of $\mathrm{pH}$ at low initial 
$\mathrm{pH}(<7)$ is ascribed to the hydrogen evolution and the generation of $\mathrm{OH}^{-}$ions at the cathodes. In alkaline medium $(\mathrm{pH}>8)$ the final $\mathrm{pH}$ does not change markedly because the generated $\mathrm{OH}^{-}$ions at the cathodes are consumed by the generated $\mathrm{Al}^{3+}$ ions at the anode forming the needed $\mathrm{Al}(\mathrm{OH})_{3}$ flocks. Furthermore, $\mathrm{OH}^{-}$ions can also partially combine with the $\mathrm{Ni}^{2+}$ ions to form the insoluble hydroxide precipitate $\mathrm{Ni}(\mathrm{OH})_{2}$.

Experiments were conducted using $\mathrm{Ni}^{2+}$ solutions of of $50 \mathrm{mg} /$ lit in the initial $\mathrm{pH}$ range 2-10. As can be obtained from Table 2 the removal efficiency of the metal ions after 20 minutes of electrolysis time at the constant current density of $20 \mathrm{~mA} / \mathrm{cm}^{2}$ reached very high values $(>97 \%)$ in the $\mathrm{pH}$ range $4-10$. The removal percent is very low at $\mathrm{pH} 2$. It increases considerably at $\mathrm{pH} 4$, remains high and almost constant in the $\mathrm{pH}$ range $4-10$ and slightly decreases at $\mathrm{pH}>10$. In alkaline medium $(\mathrm{pH}>8)$ the removal of heavy metals, beyond electrocoagulation, can also occur partially by precipitation as insoluble hydroxides as already stated. The appropriate $\mathrm{pH}$ range for effluent discharge is $5.5-9$. Furthermore, the increased solubility of $\mathrm{Al}(\mathrm{OH})_{3}$ in alkaline solutions may lead to increased Al concentration in the treated electrocoagulation effluent above the environmental standards [36]. Therefore, it is better to carry out the electrocoagulation process in this appropriate $\mathrm{pH}$ range.

Table 2. Effect of $\mathrm{pH}$ on nickel removal. Initial nickel concentration $=100 \mathrm{mg} /$ lit, current density $=20 \mathrm{~mA} / \mathrm{cm}^{2}$, electrolysis time $=15$ minutes, effective anode surface $=60$ $\mathrm{cm}^{2}$

\begin{tabular}{l|lllllllll}
\hline Initial pH & 2 & 3 & 4 & 5 & 6 & 7 & 8 & 9 & 10 \\
Removal \% & 28.1 & 84.4 & 97.5 & 98.4 & 97.4 & 98.8 & 99.6 & 98.5 & 99.2 \\
\hline
\end{tabular}

\subsubsection{Applied current density}

It is well known that the applied current density determines the coagulant dosage rate, the bubble production rate and size and the flock growth $[30,37,38]$. Adhoum et al. [30] and Colder et al. [39] used current densities between 8 and 48 $\mathrm{mA} / \mathrm{cm}^{2}$ and demonstrated that the increase of applied current density enhanced the treatment rate resulting in a faster removal of pollutants. Table 3 shows the effect of applied current density on following parameters, such as the removal rate of nickel, solution $\mathrm{pH}$, amount of generated sludge, electrical energy consumption and concentration of aluminium in the treated solution, versus time of electrolysis.

Measurements were carried out at different current densities $10-30 \mathrm{~mA} / \mathrm{cm}^{2}$, at a constant heavy metal concentration of $250 \mathrm{mg} / \mathrm{lit}$ and $\mathrm{pH}$ 7.5. According to Table 2 the removal rate of nickel increased, as expected, with increasing current density. In only 20, 30 and 40 minutes of electrolysis time at the corresponding current densities 30 , 20 and $10 \mathrm{~mA} / \mathrm{cm}^{2}$ nickel ions have been almost quantitatively removed $(>99 \%)$ and their residual concentration fell under the admissible limits $(2 \mathrm{mg} / \mathrm{lit})$ for effluents discharge to sewage systems. By doubling the applied current density from 10 to $20 \mathrm{~mA} / \mathrm{cm}^{2}$ the time of electroprocessing decreases from 40 to 30 minutes, but the overal electrical energy consumption increases almost by the factor of 3 i.e. from 3.52 to $10.207 \mathrm{wh} / \mathrm{g}$ Ni removed. (Table 3 ). The $\mathrm{pH}$ value decreased slightly to around 5 during the first stage of the electrocoagulation treatment and increased afterwards to around 8.

The aluminium concentration after the electrocoagulation treatment at the three applied current densities 10, 20 and $30 \mathrm{~mA} / \mathrm{cm}^{2}$ amounted to 365,340 and $355 \mu \mathrm{g} / \mathrm{L}$ which are in the appropriate range for effluent discharge to sewage systems.

Table 3. Effect of current density on removal efficiency of nickel with time. Initial nickel concentration $=250 \mathrm{mg} / \mathrm{lit}$, effective anode surface $=60 \mathrm{~cm}^{2}$, solution volume $=250 \mathrm{ml}$.

\begin{tabular}{|c|c|c|c|c|c|c|c|c|}
\hline $\begin{array}{l}\text { Current } \\
\text { density } \\
\left(\mathrm{mA} / \mathrm{cm}^{2}\right)\end{array}$ & $\begin{array}{l}\text { Time } \\
\text { (min.) }\end{array}$ & $\begin{array}{l}\text { Residual } \mathrm{Ni}^{2+} \\
\text { Concentration } \\
(\mathrm{mg} / \mathrm{L})\end{array}$ & $\begin{array}{l}\text { Removal } \\
\text { efficiency } \\
(\%)\end{array}$ & pH & $\begin{array}{l}\text { Al } \\
\text { consumption } \\
\text { (gAl/gNi) }\end{array}$ & $\begin{array}{l}\text { Sludge } \\
\text { amount } \\
\text { (gTSS/gNi) }\end{array}$ & $\begin{array}{l}\text { Energy } \\
\text { consumption } \\
\text { (wh/gNi) }\end{array}$ & $\begin{array}{l}\text { Al } \\
\text { concentration } \\
(\mu \mathrm{g} / \mathrm{L})\end{array}$ \\
\hline \multirow[b]{2}{*}{10} & 0 & 250.0 & & 7.5 & & & & \\
\hline & $\begin{array}{l}10 \\
30 \\
30 \\
40\end{array}$ & $\begin{array}{l}175.5 \\
48.6 \\
48.6 \\
1.9\end{array}$ & $\begin{array}{l}29.8 \\
80.6 \\
80.6 \\
99.2\end{array}$ & $\begin{array}{l}5.0 \\
6.8 \\
7.6 \\
8.1\end{array}$ & 0.655 & 3.471 & 3.52 & 360 \\
\hline 20 & $\begin{array}{l}0 \\
10\end{array}$ & $\begin{array}{l}250.0 \\
117.6\end{array}$ & 52.9 & $\begin{array}{l}7.5 \\
5.8\end{array}$ & & & & \\
\hline \multirow[b]{2}{*}{30} & $\begin{array}{l}20 \\
30\end{array}$ & $\begin{array}{l}44.8 \\
0.9\end{array}$ & $\begin{array}{l}82.1 \\
99.6\end{array}$ & $\begin{array}{l}7.7 \\
8.2\end{array}$ & 0.982 & 4.422 & 10.207 & 365 \\
\hline & $\begin{array}{l}0 \\
10\end{array}$ & $\begin{array}{l}250.0 \\
74.6\end{array}$ & 70.1 & $\begin{array}{l}7.5 \\
7.1\end{array}$ & & & & \\
\hline \multicolumn{5}{|c|}{ 3.1.3 Initial metal ion concentration } & $\begin{array}{l}\text { Table } \\
\text { concentra } \\
\text { generated } \\
\text { effluent } \\
\text { time. The } \\
\text { admissibl } \\
\text { respective } \\
\text { exists be } \\
\text { efficiency } \\
\text { for remov }\end{array}$ & $\begin{array}{l}5.128 \\
\text { shows } \\
\text { ns of nicke } \\
\text { adge, the ele } \\
\text { minium cor } \\
\text { sidual nicke } \\
\text { levels after } \\
\text { According } \\
\text { een metal } \\
\text { Certainly, fo } \\
\text { is needed, b }\end{array}$ & $\begin{array}{l}20.610 \\
\text { variations } \\
\text { he solution } \\
\text { ical energy co } \\
\text { ntration vers } \\
\text { n concentratic } \\
\text { nly } 10,15 \\
\text { Table } 3 \text {, no } \\
\text { n concentrat } \\
\text { igher concent } \\
\text { igher initial }\end{array}$ & $\begin{array}{l}365 \\
\text { the different } \\
\text { the amount of } \\
\text { imption and the } \\
\text { the electrolysis } \\
\text { were reduced to } \\
\text { d } 20 \text { minutes } \\
\text { rect correlation } \\
\text { and removal } \\
\text { ons longer time } \\
\text { entrations were }\end{array}$ \\
\hline
\end{tabular}


reduced significantly in relatively less time than lower concentrations. The electrocoagulation process is more effective at the beginning when the concentration is higher than at the end of the operation when the concentration is low.

Also here a slight decrease of $\mathrm{pH}$ is observed at the beginning of the electrocoagulation treatment which finally

Table 4. Effect of initial concentration on removal efficiency of nickel ions. Current density $=30 \mathrm{~mA} / \mathrm{cm}^{2}$, effective anode surface $=$ $60 \mathrm{~cm}^{2}$, solution volume $=250 \mathrm{ml}$.

\begin{tabular}{|c|c|c|c|c|c|c|c|c|}
\hline $\begin{array}{l}\text { Initial } \mathrm{Ni}^{2+} \\
\text { concentration } \\
\text { (mg/lit) }\end{array}$ & $\begin{array}{l}\text { Time } \\
\text { (min.) }\end{array}$ & $\begin{array}{l}\text { Residual } \mathrm{Ni}^{2+} \\
\text { concentration } \\
\text { (mg/lit) }\end{array}$ & $\begin{array}{l}\text { Removal } \\
\text { efficiency } \\
(\%)\end{array}$ & pH & $\begin{array}{l}\text { Al } \\
\text { consumption } \\
(\text { gAl/gNi) }\end{array}$ & $\begin{array}{l}\text { Sludge } \\
\text { amount } \\
\text { (gTSS/gNi) }\end{array}$ & $\begin{array}{l}\text { Energy } \\
\text { consumption } \\
(\mathrm{wh} / \mathrm{gNi})\end{array}$ & $\begin{array}{l}\text { Al } \\
\text { concentration } \\
(\mu \mathrm{g} / \mathrm{L})\end{array}$ \\
\hline
\end{tabular}

\begin{tabular}{|c|c|c|c|c|c|c|c|c|}
\hline \multirow{3}{*}{100} & 0 & 100.0 & & 7.5 & \multirow[b]{3}{*}{1.228} & \multirow[b]{3}{*}{5.140} & \multirow[b]{3}{*}{20.850} & \multirow[b]{3}{*}{340} \\
\hline & 5 & 44.3 & 55.7 & 6.0 & & & & \\
\hline & 10 & 0.9 & 99.1 & 7.2 & & & & \\
\hline \multirow{4}{*}{200} & 0 & 200.0 & & 7.5 & & & & \\
\hline & 5 & 134.8 & 32.6 & 4.9 & & & & \\
\hline & 10 & 38.9 & 80.5 & 6.1 & & & & \\
\hline & 15 & 0.8 & 99.6 & 7.8 & 0.921 & 4.733 & 15.547 & 350 \\
\hline \multirow{5}{*}{300} & 0 & 300.0 & & 7.5 & & & & \\
\hline & 5 & 230.8 & 23.1 & 4.6 & & & & \\
\hline & 10 & 141.4 & 52.8 & 5.8 & & & & \\
\hline & 15 & 51.2 & 82.9 & 6.6 & & & & \\
\hline & 20 & 1.2 & 99.6 & 7.4 & 0.818 & 3.942 & 13.641 & 345 \\
\hline
\end{tabular}

\subsection{Treatment of actual wastewaters}

The applicability of the electrocoagulation process for actual wastewater was validated by treating a sample of industrial effluent, collected from an electroplating unit (Table 1). The residual nickel concentration, solution $\mathrm{pH}$, amount of generated sludge, electrical energy consumption and aluminium concentration in the treated solution after electroprocessing versus time are shown in Table 5 .

At a constant current density of $30 \mathrm{~mA} / \mathrm{cm}^{2}$ and an electrolysis time of 20 minutes the concentration of nickel ions rapidly fell under the admissible limits.

Compared to the removal from synthetic solutions (Tables 3 and 4) the removal rate of the studied metal from wastewater increases again when nickel ions are almost quantitatively removed from the treated solutions. The aluminium concentration after the electrocoagulation treatment of the three solutions of 100, 200 and $300 \mathrm{mg} / \mathrm{L} \mathrm{Ni}$ amounted to 340,350 and $355 \mu \mathrm{g} / \mathrm{L}$ respectively, which are in the appropriate range for effluent discharge to sewage systems.

Table 5. Residual concentration and removal efficiency of nickel ions with time during the electrocoagulation treatment of the electroplating wastewater sample. Current density $=30 \mathrm{~mA} / \mathrm{cm} 2$, initial nickel concentration $=215 \mathrm{mg} /$ lit, solution volume $=$ $250 \mathrm{ml}$.

\begin{tabular}{|c|c|c|c|c|c|c|c|}
\hline Time & Residual $\mathrm{Ni}^{2+}$ concentration (mg/lit) & Removal efficiency & $\mathrm{pH}$ & Al consumption & Sludge amount & Energy consumption & Al concentration \\
\hline 0 & 215.0 & & 6.5 & & & & \\
\hline 5 & 161.2 & 25.0 & 6.0 & & & & \\
\hline 10 & 94.7 & 55.9 & 5.8 & & & & \\
\hline 15 & 37.3 & 82.6 & 6.4 & & & & \\
\hline 20 & 1.7 & 99.2 & 7.1 & 1.141 & 7.452 & 12.772 & 350 \\
\hline
\end{tabular}

\subsection{Electrode mass loss and energy consumption}

The costs in wastewater treatment with electrocoagulation are the expenditure on mass loss of electrodes and the electrical energy consumption. The mass loss of the aluminium anode $\mathrm{mAl}$ can be calculated from equation (1) using the Faraday's law:

$$
m A l=\frac{I \cdot t \cdot M}{z \cdot F \cdot m N i}
$$

where

$$
I=\text { current intensity (A) }
$$$$
t=\text { time (s) }
$$

seems to be slower. This should be attributed to the presence of the organic compounds, which also compete for absorption on the $\mathrm{Al}(\mathrm{OH})_{3}$ flocks resulting in a substantial reduction of the metal ions removal. As known, various other organics, beyond complex former, are added to the electroplating baths, such as brighteners, buffering and wetting agents. The COD of the wastewater decreased from the initial value of $324 \mathrm{mg} / \mathrm{L}$ to $126 \mathrm{mg} / \mathrm{L}$ after $25 \mathrm{~min}$, which corresponds to a removal efficiency of about $61 \%$. Consequently, electrocoagulation is an effective method for removing simultaneously both, heavy metals and organic compounds from wastewater.

$M=$ Molecular weight of Aluminium $(\mathrm{g} / \mathrm{mol})$

$z=$ number of electrons transferred in the reaction $\mathrm{Al} \rightarrow$ $\mathrm{Al}^{3+}+3 \mathrm{e}^{-}$

$F=$ Faraday's constant $(96500 \mathrm{Cb} / \mathrm{mol})$

$m \mathrm{Ni}=$ mass of nickel removed from wastewater.

The calculated mass loss of the sacrificial aluminium anode for electrocoagulation of the treated electroplating wastewater is $0.936 \mathrm{~g} \mathrm{Al} / \mathrm{g} \mathrm{Ni}$ removed from wastewater. However, due to additional chemical dissolution of aluminium in alkaline and acidic conditions in the vicinity of cathode and anode respectively, the experimentally measured aluminium consumption is somehow higher amounting to $1.141 \mathrm{~g} \mathrm{Al} / \mathrm{g} \mathrm{Ni}$. Aluminium electrode consumptions after electrocoagulation treatment for all synthetically prepared nickel containing wastewater samples are given Tables 3 and 4 . 
Similarly, the electrical energy consumption $E$ is calculated from equation (2):

$E=\frac{U \cdot I \cdot t}{m N i}$

where

$U=$ voltage (Volts)

The energy consumption for electrocoagulation treatment of the electroplating wastewater amounts to $12.772 \mathrm{wh} / \mathrm{g}$ Ni removed from treated wastewater. Electrical energy consumptions for the treated synthetically prepared wastewaters are shown in Tables 3 and 4.

\subsection{Sludge ammount}

The precipitated sludge was collected, dried at $103{ }^{\circ} \mathrm{C}$ for 24 $\mathrm{h}$, cooled in a desiccator and weighed. It consists of nickel in form of $\mathrm{Ni}(\mathrm{OH})_{2}$ and aluminium in form of $\mathrm{Al}(\mathrm{OH})_{3}$ in case of the treated synthetically prepared samples and additionally of absorbed organic substances in case of the treated actual electroplating wastewater. Its amount is based on the Faraday's law. The measured sludge amounts for the electrocoagulation treatment of the synthetically prepared solutions and the actual electroplating wastewater are given in Tables 3, 4 and 5 as mass in $g$ of Total Suspended Solids per mass in $\mathrm{g}$ of nickel removed from treated solution (gTSS/gNi). The electrocoagulation treatment produces apparently less sludge compared to that produced by the conventional chemical coagulation process.

\section{Conclusions}

Electrocoagulation with aluminium electrodes is a safe and convenient route for effective removal of heavy metals, such as nickel from water and wastewater. Best removal capacity was achieved in the $\mathrm{pH}$ range 4-8. Removal rate increased with increasing applied current density. The nickel concentrations in synthetic solutions and industrial wastewater fell under the admissible limits in only 15 and 20 minutes respectively. Dissolved organic compounds present in electroplating wastewater are also removed. In comparison to chemical coagulation, where an increased coagulant dosage and several hours are needed, electrocoagulation is a faster and more economical method for removing metallic and organic pollutants from water and industrial effluents.

\section{References}

1. P. Patnaik, A comprehensive guide to the hazardous properties of Chemical Substances, second ed., Wiley, New York, 1999.

2. P. Mavros, A.I. Zouboulis, N.K. Lazaridis, Environm. Technol. 14, 83 (1993).

3. S. Triantafyllou, E. Christodoulou, P. Neou-Synguna, Clays \& Clay Minerals 47, 567 (1999).

4. L. Wu, J. Yu, X. Sun, B. Li, Environm. Progr. \& Sust. Energy 28, $234(2008)$.

5. K.A. Matis, A.I. Zouboulis, N.K. Lazaridis, Water, Air \& Soil Pollution 3, 143 (2003).

6. M.A. Keane, Colloids Surf. A. Psysicochem. Engin. Aspects 138, 11 (1998).

7. Tünay, O. and Kabdaşlı, N. I., Water Res., 28, 2117 (1994).

8. P. Papachristou, K.J. Haralambous, M. Loisidou, N. Spyrellis, $J$. Environm. Sci. Health, Part A: Toxic/Hazard. Subst. Environm. Eng. 28, 135 (1993).

9. P.T. Bolger, D.C. Szlag, Environm. Progr. 21, 203 (2004).

10. C-Ho Huang, Water Res. 29, 1821 (1995).

11. C. L. Li, X. X. Zhao, T. Tsuru, D. Zhou, M. Matsumura, J. Membr. Sci. 157, 241 (1999).

12. H. Lu, J. Wang, B. Yan, S. Bu, Water Sci. Technol. 61, 729 (2010).

13. K H., Yeon J H. Seong, S. Rengaraj, S. H Moon, Sep. Sci. Technol. 38, 443 (2003).

14. K. Dermentzis, J. Hazard. Mater. 173, 647 (2010).

15. K. Dermentzis, A. Davidis, A. Dermentzi, C. Chatzichristou, Water Sci. Technol. 62, 1947 (2010).

16. K. Dermentzis, A. Christoforidis, D. Papadopoulou, A. Davidis, Environm. Progr. \& Sust. Energy, 30, 37 (2011).

17. Tünay, O., Kabdaşl1, N. I., and Hung, Y. (2004). Metal Finishing Industry. in Handbook of Industrial Hazardous Waste Treatment. Marcel Dekker Inc., 2nd ed. Revised and Expanded. Editors: Wang, L. K., Hung, Y., Lo, H. H., and Yapijakis, C. (ISBN 0-82474114-5) (e-book).

18. M. Kobya, O.T. Can, M. Bayramoglu, J. Hazard. Mater. B100, 163 (2003).

19. G.B. Raju, M.T. Karuppiah, S. S. Latha, S. Parvathy, S. Prabhakar, Chem. Eng. J. 144, 51 (2008).

20. O. Abdelwahab, N.K. Amin, E-S.Z. El-Ashtoukhy, J. Hazard. Mater. 163, 711 (2009).
21. U.T. Un, A.S. Koparal, U.B. Ogutveren, J. Environm. Manag. 90, 428 (2009).

22. S. Tchamango, C.P. Nanseu-Njiki, E. Ngameni, D. Hadjiev, A. Darchen, Sci. Tot. Environm. 408, 947 (2010).

23. O. Chavalparit, M. Ongwandee, J. Environm. Sci. 21, 1491 (2009).

24. M.H. El-Naas, S. Al-Zuhair, A. Al-Lobaney, S. Makhlouf, $J$. Environm. Manag. 91, 180 (2009).

25. Chin-Ta Wang, Wei-Lung Chou, Yi-Ming Kuo, J. Hazard. Mater. 164, 81 (2009).

26. M. Asselin, P. Drogui, H. Benmoussa, J-F. Blais, Chemosphere, 72, 1727 (2008).

27. H.K. Hansen, P. Nunez, D. Raboy, I. Schippacase, R. Grandon, Electrochim. Acta 52, 3464 (2007).

28. C-Y. Hu, S-L. Lo, W.H Kuan, Y.D. Lee, Sep. Purif. Technol. 60, 1 (2008)

29. Kabdaşlı, I. Arslan, T., Ölmez-Hanc1, T., Arslan-Alaton, I. and Tünay, O., J. Hazard. Mater., 165, 838 (2009).

30. N. Adhoum, L. Monser, N. Bellakhal, J-E. Belgaied, J. Hazard. Mater. B112, 207 (2004).

31. J. Nouri, A.H. Mahvi, E. Bazrafshan, Intern. J. Environm. Res. 4, $201(2010)$

32. Körbahti B. K., Artut K., Gecgel C., Öyer A., Chem. Engin. J., Doi: 10.1016/j.cej.2011.02.018.

33. K. Dermentzis, A. Christoforidis, E. Valsamidou, Intern. J. Environm. Sci., 1, 697 (2011).

34. Kabdaşl1, I. Arslan, T., Ölmez-Hanc1, T., Arslan-Alaton, I. and Tünay, O., J. Hazard. Mater., 165, 838 (2009).

35. E.A. Vik, D.A. Carlson, A.S. Eikum, E.T. Gjessing, Water Res. 18, 1355 (1984).

36. K. Bensadok, S. Benammar, F. Lapicque, G. Nezzal, J. Hazard. Mater. 152, 423 (2008).

37. Holt P K, Barton G W, Wark M, Mitchell C A, Colloids Surf. A: Physicochem. Eng. Aspects 211, 233 (2002).

38. N.K. Khosla, S. Venkachalam, P. Sonrasundaram, J. Appl. Electrochem., 21, 986 (1991).

39. A.K. Colder, V. Dhaneesh, A.N. Samanta, S. Ray, Chem. Eng. Technol. 1, 143 (2008). 